\title{
Penggunaan Media Pembelajaran Diorama untuk Meningkatkan Pemahaman Konsep Kelas IV SD Negeri 2 Hadipolo
}

\author{
Ayu Dandini Kisma, Fina Fakhriyah, Imaniar Purbasari \\ Universitas Muria Kudus, Jl. Lkr. Utara, Kayuapu Kulon, Gondangmanis, Kec. Bae, Kabupaten Kudus, \\ Jawa Tengah 59327 \\ Correspondence Email: Ayudandiniı@@gmail.com
}

\begin{abstract}
Abstrak
Penelitian ini bertujuan untuk mendeskripsikan peningkatan pemahaman konsep dengan media diorama. Metode penelitian yang digunakan yang penelitian tindakan kelas (PTK). Subjek penelitian ini yaitu siswa kelas IV SD Negeri 2 Hadipolo yang berjumlah 35 siswa. Teknik pengumpulan data melalui pengamatan, wawancara, dokumentasi, dan data tes tertulis di akhir siklus. Teknik analisis data yang digunakan observasi, dan tes. Hasil penelitian menunjukkan bahwa pemahaman konsep pada pra siklus memperoleh rata-rata 68, 98 dengan kriteria perlu bimbingan. Hasil tes pemahaman konsep pada siklus I memperoleh rata-rata 73, 72 dengan kriteria perlu bimbingan, dan hasil tes pemahaman konsep siklus II memperoleh rata-rata 85, o5 dengan kriteria baik. Simpulan media diorama dapat meningkatkan pemahaman konsep siswa pada materi sumber daya alam.
\end{abstract}

Kata Kunci:

Pemahaman Konsep, Diorama; Kelas IV SD

\begin{abstract}
This study aims to describe the increase in understanding of concepts with diorama media. The research method used was classroom action research (CAR). The subjects of this study were 35 students in grade IV SD Negeri 2 Hadipolo. Data collection techniques through observation, interviews, documentation, and written test data at the end of the cycle. Data analysis techniques used observation, and tests. The results showed that the understanding of the concepts on the prasilus obtained an average of 68,98 with the criteria needed guidance. The results of understanding the concept of the cycle I obtained an average of 73, 72 with the criteria need guidance, and the results of the understanding of the concept of the second cycle obtained an average of 85, o5 with good criteria. Conclusions from diorama media can enhance students' understanding of concepts in natural resource material.
\end{abstract}

Keywords:

Concept Understanding, Diorama; Class IV SD

\section{Pendahuluan}

Pembelajaran adalah proses interaksi antara guru dan murid agar dapat belajar dengan baik. Dalam pembelajaran melibatkan siswa, guru serta sumber belajar, guru memfasilitasi siswa agar dapat belajar lebih baik. Adanya interaksi guru dan siswa akan terjadi pembelajaran yang efektif. Pembelajaran yang efektif yaitu pembelajaran yang memudahkan siswa untuk mempelajari sesuatu yang bermanfaat serta fakta, keterampilan, nilai, konsep dan bagaimana hidup serasi dengan sesama atau hasil belajar yang diinginkan (Susanto, 2013). Dalam pembelajaran guru memfasilitasi siswa agar dapat belajar dengan baik. Adanya siswa yang mampu mencerna materi pembelajaran dan siswa yang lambat dalam mencerna materi pembelajaran merupakan perbedaan dalam belajar. Tujuan dalam pembelajaran untuk 
mengetahui dan memahami suatu istilah dan konsep diharapkan siswa dapat menerapkan dan mengembangkan pemahamannya.

Menurut Bloom (Susanto, 2013) bahwa pemahaman merupakan kemampuan siswa dalam menerima, menyerap dan memahami pelajaran yang diberikan guru kepada siswa untuk mengetahui sejauh mana siswa mampu mengerti apa yang siswa baca, yang dilihat, dialami, atau yang siswa rasakan berupa hasil penelitian atau observasi langsung yang siswa lakukan. Sedangkan Menurut Santrock (Hendayani , 2018) bahwa konsep merupakan kategori yang mengelompokkan objek, kejadian dan karakteristik berdasarkan bentuk-bentuk yang sama. Konsep mampu membantu dalam proses mengingat menjadi lebih efisien. Pemahaman konsep sangat berpengaruh terhadap hasil belajar siswa, mudahnya penguasan siswa memahami materi pada saat kegiatan pembelajaran maka hasil belajar siswa juga akan meningkat. Dapat disimpulkan bahwa pemahaman konsep merupakan tingkat kemampuan siswa dalam mengerti, memahami materi, serta mampu menjelaskan dengan kata-katanya sendiri.

Menurut Hamzah B. Uno dan Satria Koni (Handayani \& Wardani, 2015: 70) bahwa indikator pemahaman konsep terdiri dari

a. Menyatakan ulang sebuah konsep
b. Mengklasifikasikan objek-objek menurut sifat-sifat tertentu (sesuai dengan konsepnya)

c. Memberi contoh dan noncontoh dari konsep

d. Menyajikan konsep dalam berbagai bentuk representasi matematis

e. Mengembangkan syarat perlu atau syarat cukup suatu konsep

f. Menggunakan, memanfaatkan, dan memilih prosedur atau operasi tertentu

g. Mengaplikasikan konsep atau algoritma pemecahan masalah.

Berdasarkan hasil observasi dan wawancara pada tanggal 28 Oktober 2019 di SD Negeri 2 Hadipolo dalam pembelajaran kurikulum 2013 pada saat kegiatan pembelajaran di temukan banyak siswa kurang menguasai kompetensi dasar pengetahuan pada muatan IPS terutama pada materi sumber daya alam dan kegiatan ekonomi. Siswa menganggap materi tersebut sulit, karena terlalu banyak materi yang diingat. Selain itu masih banyak siswa yang menanyakan materi yang sudah dijelaskan berulangulang oleh guru bahkan terkadang masih ada siswa yang bertanya setelah pertanyaan itu ditanyakan karena siswa kurang memperhatikan penjelasan. Dalam kegiatan berlangsung, siswa merasa antusias dalam menyelesaikan tugas tetapi hasil pekerjaan siswa dikoreksi oleh guru masih ada jawaban yang kurang tepat.

Hasil observasi juga menunjukkan bahwa mengembangkan syarat perlu dan syarat cukup suatu konsep masih rendah. Hanya ada satu hingga tiga siswa yang mampu mengembangkan konsep berpikirnya. Ketika guru menjelaskan materi jenis-jenis pekerjaan dengan menggambarkan suatu kota besar siswa diminta guru untuk menyebutkan jenisjenis pekerjaan yang terdapat pada gambar hanya satu sampai tiga siswa yang mampu menyebutkan jenis-jenis pekerjaan sesuai dengan gambar. Hal ini menunjukkan bahwa siswa belum dapat mengembangkan syarat perlu dan syarat cukup suatu konsep dengan baik. Oleh karena itu penggunaan media pembelajaran diharapkan mampu menumbuhkan pemahaman konsep terutama dalam pada indikator menyatakan ulang sebuah konsep, memberi contoh dan noncontoh dari konsep, mengklasifikasi objek-objek menurut sifat-sifat tertentu, menyajikan konsep dalam berbagai bentuk 
representasi matematis, mengembangkan syarat perlu dan syarat cukup suatu konsep, menggunakan memanfaatkan dan memilih prosedur atau operasi tertentu, dan mengaplikasikan konsep atau algoritma pemecahan masalah.

Berdasarkan permasalahan tersebut, salah satu untuk meningkatkan rendahnya pemahaman konsep siswa yaitu dengan menggunakan media pembelajaran yang menarik bagi siswa. Media Pembelajaran merupakan alat bantu atau bahan guna mempermudah guru dalam menyampaikan pembelajaran agar dapat merangsang siswa dalam belajar. Media juga sebagai sarana untuk meningkatkan kegiatan proses belajar mengajar. Media pembelajaran juga sangat berpengaruh terhadap hasil belajar siswa. Bentuk media diorama yang biasanya digunakan sebagai tiruan pemandangan mampu membantu siswa dalam memahami materi sumber daya alam. Menurut Sanjaya (2013) bahwa media diorama merupakan sebuah pemandangan tiga dimensi yang bertujuan untuk menggambarkan pemandangan sebenarnya. Media diorama mampu memberikan pengalaman kepada siswa secara langsung, membantu siswa dalam memahami materi, membuat siswa aktif dalam kegiatan belajar serta membuat kegiatan belajar lebih menarik (Wafa \& Rizkyana, 2019). Dapat disimpulkan bahwa media diorama merupakan sebuah tiruan pemandangan tiga dimensi sehingga mampu memberikan pengalaman secara langsung oleh siswa.

Peneliti menggunakan media diorama untuk membantu meningkatkan pemahaman konsep siswa. Penggunaan media diorama sangat mendukung dalam proses pembelajaran. Diorama untuk menggabungkan materi IPS sumber daya alam dan muatan Bahasa Indonesia puisi. Media pembelajaran mampu menarik siswa agar fokus dalam pembelajaran serta tercapainya tujuan pembelajaran. Media diorama dapat memudahkan siswa dalam memahami suatu konsep atau materi. Penelitian ini bertujuan untuk mendeskripsikan peningkatan pemahaman konsep dengan media diorama.

\section{Metode Penelitian}

Rancangan dalam penelitian ini adalah penelitian tindakan kelas (PTK). Penelitian ini dilakukan di SD Negeri 2 Hadipolo. Subjek penelitian yaitu 35 siswa kelas IV SD negeri 2 Hadipolo. Jenis penelitian tindakan kelas ini menggunakan model desain Kemmis dan MC Taggart yang terdiri dari empat tahapan yaitu 1) perencanaan 2) pelaksanaan 3) pengamatan 4) refleksi.

Pada tahap perencanaan yaitu peneliti merancang silabus pembelajaran, Rencana Pelaksanaan Pembelajaran (RPP), menyiapkan lembar observasi keterampilan guru. Tahap kedua, pelaksanaan tindakan yaitu melaksanakan kegiatan pembelajaran sesuai dengan silabus, dan Rencana Pelaksanaan Pembelajaran (RPP) yang telah dirancang dan menerapkan penggunaan media diorama untuk meningkatkan pemahaman konsep siswa. Penggunaan media diorama diterapkan diterapkan dengan model pembelajaran secara langsung. Pada tahap ketiga, pengamatan yaitu untuk mengamati keadaan guru dan siswa pada saat kegiatan pembelajaran secara langsung. Pengamatan ini dilakukan oleh pengamat. Pada tahap keempat, refleksi untuk memberikan penilaian dan mengetahui kekurangan maupun kelebihan yang terdapat pada kegiatan pembelajaran secara langsung. Teknik pengumpulan data dalam penelitian ini yaitu berupa 1) tes yang digunakan untuk mengukur pemahaman konsep siswa pada materi puisi dan 
sumber daya alam. Jenis tes yang digunakan yaitu tes tertulis yang berupa soal uraian 2) Observasi digunakan untuk mengamati dan mencatat kegiatan pembelajaran dalam situasi yang sebenarnya maupun dalam situasi buatan untuk mencapai tujuan tertentu. Dilakukan dengan bantuan guru kelas, dan teman sejawat dengan menggunakan lembar observasi guru dan lembar observasi siswa pada saat kegiatan pembelajaran berlangsung yang dilaksanakan dengan menggunakan media diorama.

Teknik analisis data dalam penelitian ini yaitu berupa 1) analisis data kualitatif digunakan untuk megetahui kendalakendala yang tejadi pada saat pelaksnaan pembelajaran 2) analisis data kuantitatif dari tes pada akhir siklus yang mengacu pada tingkat kriteria pemahaman konsep pada muatan Bahasa Indonesia dan IPS.

Tabel 1. Kriteria Pemahaman Konsep Bahasa Indonesia dan IPS

\begin{tabular}{cccc}
\hline Rentang Skor & Nilai & Kriteria & Kategori \\
\hline $64-70$ & $92<\mathrm{x} \leq 100$ & Sangat Baik & $\mathrm{A}$ \\
$68-64$ & $83<\mathrm{x} \leq 92$ & Baik & $\mathrm{B}$ \\
$52-68$ & $75<\mathrm{x} \leq 83$ & Cukup & $\mathrm{C}$ \\
$<52$ & $\leq 75$ & Perlu Bimbingan & $\mathrm{D}$ \\
\hline
\end{tabular}

\section{Hasil dan Pembahasan}

Penelitian dilakukan di SD Negeri 2 Hadipolo. Data diperoleh dengan menggunakan instrumen wawancara siswa dan guru, observasi pembelajaran di kelas IV serta tes pra siklus. Lembar wawancara siswa dan guru diberikan pertanyaan dengan wawancara terstruktur yang berisi tentang indikator pemahaman konsep, observasi pembelajaran dan tes pra siklus untuk mendeskripsikan pemahaman konsep siswa yang berkaitan dengan puisi dan sumber daya alam.

Bentuk diorama yang digunakan peneliti yaitu berisi miniatur rumah, pegunungan, sawah, dan laut serta. Peneliti membuat diorama miniatur rumah dan gedung yang terbuat dari kayu, sawah dengan hiasan rumput-rumputan, serta lautan dengan menggunakan stiker dan sedikit pasir laut ditempel di pinggiran sehingga terbentuk seperti laut sungguhan. Media pembelajaran diorama ini digunakan peneliti pada siklus I dan siklus II, setiap siklus yang terdiri dari 2 pertemuan. Berikut gambar media diorama yang digunakan peneliti dalam melakukan penelitian.

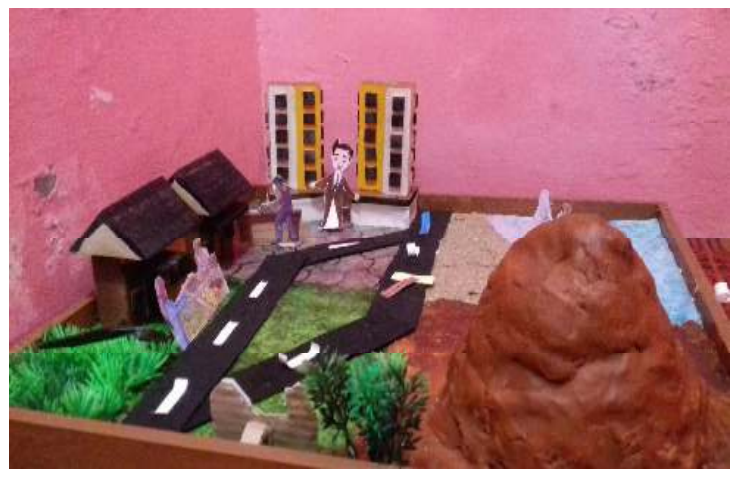

Gambar 1. Media diorama

Berdasarkan hasil wawancara, peneliti menemukan beberapa masalah dalam muatan Bahasa Indonesia dan IPS, masih banyak siswa yang belum menguasai indikator pemahaman konsep. Sebagian siswa sudah mampu menyatakan ulang sebuah konsep, siswa masih kebingungan 
untuk mengenali objek berdasarkan sifatnya, siswa dengan bantuan guru mampu membedakan contoh dan noncontoh.

Pada indikator pemahaman konsep siswa masih rendah dalam mengembangkan syarat perlu dan syarat cukup suatu konsep. Hal ini dibuktikan pada materi menganalisis cara menjaga kelestarian alam, masih banyak siswa yang menjawab menanam pohon dan tidak membuang sampah sembarangan. Siswa juga masih terikat dengan penghafalan, siswa hanya meniru penyelesaian soal yang berbeda sehingga siswa bingung dengan jawaban yang tidak tepat. Siswa belum dapat mengembangkan syarat perlu dan syarat cukup suatu konsep yang diperlukan untuk menyelesaikan soal karena siswa masih terpaku pada hafalan (Pujiati, Kanzunnudin, \& Wanabuliandari, 2018). Hal itu membuktikan bahwa siswa kurang mengusai indikator pemahaman konsep. Penguasaan pemahamanan sangat diperlukan siswa dalam memahami materi yang sedang diajarkan. Ketika siswa sudah dapat memahami konsep dengan baik maka siswa dapat dengan mudah dalam menyelesaikan permasalahan yang terdapat dalam soal sehingga ketuntasan belajar tercapai baik secara individu maupun klasikal (Rosmayadi, Mariyam, \& Juliyanti, 2018).

Tabel 2. Penilaian Pemahaman Konsep

\begin{tabular}{clccc}
\hline \multirow{2}{*}{ No } & \multicolumn{1}{c}{ Indikator } & \multicolumn{3}{c}{ Hasil } \\
\cline { 2 - 5 } 1. & Menyatakan ulang sebuah konsep & 70 & 72,49 & 88,58 \\
\hline 2. & $\begin{array}{l}\text { Memberi contoh dan noncontoh dari } \\
\text { konsep }\end{array}$ & 75 & 75,71 & 83,23 \\
\hline 3. & $\begin{array}{l}\text { Mengklasifaikasi objek-objek } \\
\text { menurut sifat-sifat tertentu (sesuai } \\
\text { dengan konsepnya) }\end{array}$ & 70,71 & 73,57 & 82,23 \\
\hline 4. & $\begin{array}{l}\text { Menyajikan konsep dalam berbagai } \\
\text { bentuk representasi matematis }\end{array}$ & 70,71 & 73,43 & 82,84 \\
\hline 5. & $\begin{array}{l}\text { Mengembangkan syarat perlu dan } \\
\text { syarat cukup suatu konsep }\end{array}$ & 60 & 73,56 & 83,55 \\
\hline 6. & $\begin{array}{l}\text { Menggunakan, memanfaatkan dan } \\
\text { memilih prosedur atau operasi } \\
\text { tertentu }\end{array}$ & 62 & 72,85 & 89,66 \\
\hline 7. & $\begin{array}{l}\text { Mengaplikasi konsep atau algoritma } \\
\text { pemecahan masalah }\end{array}$ & 73.57 & 74,28 & 83,93 \\
\hline Nilai rata-rata & 68,98 & 73,72 & 85,05 \\
\hline
\end{tabular}

Berdasarkan uraian pada tabel 2. terdapat peningkatan pemahaman konsep pada muatan Bahasa Indonesia dan IPS dari siklus ke siklus. Pemahaman konsep pra siklus memperoleh nilai 68, 98 dengan 9 siswa yang tuntas. Setelah diadakannya tindakan pada siklus I pemahaman konsep memperoleh nilai 73,72 dengan 14 siswa yang tuntas. Tindakan pada siklus II pemahaman konsep memperoleh nilai 85 , o5 dengan 35 siswa yang tuntas. Indikator pemahaman konsep meningkat di setiap 
siklusnya. Pemaparan diatas dapat dikatakan bahwa penggunaan media diorama dapat meningkatkan pemahaman konsep. Penggunaan media diorama meningkatkan hasil belajar tematik siswa, penggunaan media tersebut dapat menimbulkan rasa ingin tahu terhadap materi yang akan dipelajari karena bentuknya menarik sehingga siswa untuk menggunakannya dalam proses pembelajaran (Nurkamaliah, Damayani, \& Ardiyanto, 2018).

Peneliti menemukan beberapa masalah pada saat setelah dilakukannya tindakan siklus I yaitu siswa masih ramai sendiri ketika guru menyampaikan materi, masih ada siswa yang sibuk bermain bolpoin, ngobrol dengan temannya sebangku. Apabila siswa fokus memperhatikan guru ketika menjelaskan materi maka siswa akan lebih mudah menerima materi yang disampaikan oleh guru. Sejalan dengan pendapat Ismilasari (2013: 8) bahwa memperhatikan siswa yang duduk didepan maupun dibelakang, sehingga siswa tersebut tidak mempunyai kesempatan untuk ramai sendiri atau melakukan hal-hal kegaduhan. Siswa awalnya tidak fokus dalam memperhatikan penjelasan guru, lama kelamaan siswa mau memperhatikan penjelasan guru sehingga materi tersebut bisa diterima oleh siswa dengan baik. Hal tersebut menyebabkan pada peningkatan pemahaman konsep siswa siklus I.

Selanjutnya, siswa belum bisa mandiri dalam mengerjakan soal LKS. Siswa masih bergantung kepada temannya karena siswa merasa bahwa temannya mampu menyelesaikan LKS tanpa bantuan dirinya. Hal tersebut menjadikan dalam suatu kelompok tidak mau mengerjakan LKS sehingga siswa tidak melakukan diskusi dengan kelompoknya masingmasing.

Dari ketujuh indikator pemahaman konsep, siswa masih rendah dalam menyatakan ulang sebuah konsep. Siswa belum bisa menemukan kembali konsep yang telah diamati melalui media diorama. Hal ini dapat dilihat dari pekerjaan siswa ketika menjawab soal. Berdasarkan indikator menyatakan ulang sebuah konsep pada materi sumber daya alam dan puisi, masih ada siswa yang kurang tepat dalam materi mendefinisikan aktivitas penduduk dengan tepat. Siswa justru menjawab dengan menyebutkan jenis jenis sumber daya alam yaitu sumber daya alam dapat diperbarui dan tidak dapat diperbarui. Sedangkan pada materi puisi indikator menyatakan ulang sebuah konsep siswa menjawab terkait dengan ciri-ciri puisi yaitu terdiri dari tema, irama, dan bait. Hal tersebut membuktikan bahwa siswa dalam menyajikan ulang sebuah konsep sumber daya alam dan puisi masih rendah. Sehingga hasil pekerjaan siswa masih terdapat jawaban masih sesuai dengan teori atau penjelasan guru, siswa belum bisa menangkap media diorama dengan menemukan ulang sebuah konsep. Melalui media pembelajaran diorama siswa tidak hanya menerima materi atau konsep dari guru, akan tetapi siswa mampu menemukan konsep dengan sendirinya melalui media diorama yang membantu imajinasi siswa. Sejalan dengan pendapat Pratiwi (2014) yang menyatakan bahwa dengan adanya media diorama siswa dapat dengan mudah mengkonkretkan materi pembelajaran yang bersifat abstrak sehingga pembelajaran terasa mudah dimengerti karena mereka tidak perlu mengkhayalkan apa yang dimaksud oleh materi yang sedang dipelajari namun dapat melihatnya secara langsung walau hanya dengan miniatur., sehingga memotivasi siswa dalam menerima pembelajaran yang sedang berlangsung.

Sedangkan pada siklus II siswa masih rendah dalam indikator mengklasifikasi objek-objek menurut sifat-sifat tertentu (sesuai dengan konsepnya). Hal itu 
dibuktikan pada materi mengidentifikasi manfaat sumber daya alam di lingkungan sekitar dimana siswa masih belum tepat dalam mengelompokkan manfaat air dan manfaat sayuran. Siswa justru menjawab dengan menyebutkan jenis-jenis sumber daya alam yaitu sumber daya alam yang dapat diperbarui dan tidak dapat diperbarui. Sedangkan pada materi puisi siswa belum bisa mengelompokkan puisi yang memiliki amanat yang sama. Hal ini dibuktikan pada materi membuat puisi berdasarkan sumber daya alam dilingkungan sekitar, siswa diminta untuk memilih salah satu objek sumber daya alam yang akan dibuat puisi akan tetapi masih ada siswa yang kesulitan dalam membuat puisi tersebut dikarenakan siswa kurang memahami ciri-ciri puisi yang baik dan benar. Sejalan dengan pendapat Hamid (2019) bahwa pada indikator mengklasifikasi objek-objek tertentu siswa banyak yang mengartikan maksud dari soal a, b, c yang bukan pilihan ganda mereka justru memilih salah satu objek yang diminta.

Peningkatan pemahaman konsep dari siklus I dan siklus II yaitu dengan memberikan motivasi kepada siswa yang berupa hadiah ataupun hukuman serta memperbaiki kegiatan pembelajaran agar pembelajaran menjadi lebih efektif. Pada siklus II guru lebih memberikan motivasi kepada siswa berupa penghargaan serta guru juga memberikan hukuman bagi siswa yang masih ramai dalam kegiatan pembelajaran, dan tidak mau ikut berdiskusi dengan teman sekelompoknya. Guru memberikan hukuman bagi siswa yang berupa peringatan, guru juga menegaskan materi dan lebih mengoptimalkan penggunaan media diorama dikaitkan dengan materi agar siswa mudah dalam menerima dan memahami materi. Selain itu, guru juga memberikan motivasi kepada siswa agar tidak mengulangi kesalahan tersebut
(Ernata, 2017: 784). Motivasi bagi siswa juga sangat berpengaruh terhadap minat dan semangat belajar siswa dalam proses pembelajaran. Sehingga siswa bersungguh-sungguh dalam kegiatan pembelajaran. Media diorama untuk memberikan konsep seutuhya pada anak, selain itu juga menarik minat serta ketertarikan siswa terhadap apa yang sedang dipelajari. (Jannah \& Basit, 2019).

\section{Simpulan}

Berdasarkan hasil penelitian dan pembahasan, media diorama dapat meningkatkan pemahaman konsep siswa pada muatan IPS kelas IV SD Negeri 2 Hadipolo. Pernyatan tersebut ditunjukkan adanya peningkatan pemahaman konsep pada siklusnya melalui tes evaluasi di akhir siklus. Peningkatan pemahaman konsep pada siklus I memperoleh ratarata sebesar 73,72 dengan kriteria perlu bimbingan, sedangkan pemahaman konsep pada siklus II memperoleh ratarata sebesar 85, o5 dengan kriteria baik. Maka bisa dikatakan bahwa media diorama dapat meningkatkan pemahaman konsep siswa pada muatan IPS.

\section{Daftar Pustaka}

Amalia, M. D. dkk. (2017). Pengembangan Media Diorama Dalam Pembelajaran Tematik Terintegrasi Tema Indahnya Negeriku Untuk Meningkatkan Hasil Belajar. Jurnal Penelitian Pendidikan, 20(2), 185-198.

Ernata, Yusvida (2017). Analisis Motivasi Belajar Peserta Didik Melalui Pemberi Rewerd dan Punishment di SD Ngaringan 05 Kec. Gandusari Kab. Blitar. E-jurnal IKIP Budi Utomo Malang, 5(2), 781-790.

Hamid, Nurdin., Arvyaty., Ikman. (2019) Pengaruh Model Pembelajaran Berbasis Masalah Terhadap Kemampuan Pemahaman Konsep 
Matematis Siswa Kelas VIII SMP KESEHATAN MANDONGA. Jurnal Penelitian Pendidikan Matematika, $7(2)$.

Handayani, ML. Dri. \& Wardani, W.W. (2015). Upaya Meningkatkan Pemahaman Konsep Matematika Melalui Model Pembelajaran Problem Solving Pada Siswa Kelas VIII D SMP N I KASIHAN. Jurnal Derivat, 2(1), 68-75.

Hendayani, Santi ( 2018) Penerapan Strategi Reciprocal Teaching untuk Peningkatan Pemahaman Konsep Peserta Didik Pada Pembelajaran Ips. Jurnal JPGMI, 4 (2), 102-12.

Ismilasari, Yaashinta. (2013). Penggunaan Media Diorama Untuk Meningkatkan Keterampilan Menulis Karangan Narasi Pada Siswa Sekolah Dasar. JPGSD, 1(2), 8.

Jannah M., Basit, A. (2019). Penerapan Media Diorama Untuk Meningkatkan Hasil Belajar. Jurnal Terapung, 1(2).

Nurkamaliah, A. dkk. (2018). Pengaruh Pembelajaran Mind Mapping Berbantuan Media Diorama Terhadap Hasil Belajar Siswa Pembelajaran Tematik Kelas IV SD Muhammadiyah 1 Pekalongan. Jurnal Guru Kita, 2(3), 65-73.

Pratiwi, S. dkk ( 2014). Pengaruh Model Brain-Based Learning Berbantuan Media Diorama Terhadap Hasil Belajar IPS Siswa Kelas V SD Gugus VII Sukawati Tahun Ajaran 2013/ 2014. Jurnal Mimbar PGSD Universitas Pendidikan Ganesha, 2(1).

Pujiati, dkk. (2018) Analisis Pemahaman Konsep Matematis Siswa Kelas IV SD Negeri 3 Gemulung Pada Materi Pecahan. Jurnal Ilmiah Pendidikan Matematika, 1(1), 38.

Sudjana, Nana. (2013). Dasar-Dasar Proses Belajar Mengajar. Bandung: Sinar Baru Algesindo.
Susanto, Ahmad. (2013). Teori Pembelajaran di Sekolah Dasar. Jakarta: PRENADA MEDIA GROUP. Wafa, M. I., \& Rizkyana, R. F. (2019). Penggunaan Media Diorama Terhadap Hasil Belajar Kognitif Siswa di SDN 2 Sudorokan. Jurnal Lensa Pendas, 4(2), 115-120. 